Kinestetik : Jurnal Ilmiah Pendidikan Jasmani 5 (3) (2021)

Kinestetik : Jurnal Ilmiah Pendidikan Jasmani

https://ejournal.unib.ac.id/index.php/kinestetik/index

DOI : 10.33369/jk.v5i3.17853

\title{
PARENTS PERCEPTIONS OF ONLINE LEARNING VIDEOS PHYSICAL EDUCATION AND SPORTS HEALTH IN STATE ELEMENTARY SCHOOL
}

\author{
Rahmadi $^{1 *}$ Syamsul Arifin ${ }^{2}$, M. Sultan Almalik ${ }^{3}$ \\ ${ }^{123}$ Faculty of Teacher Training Education, Universitas Lambung Mangkurat, Indonesia
}

\section{Article Info}

Article History :

Received : September 2021

Revised : September 2021

Accepted : September 2021

Available online : September

2021

Keywords:

Perception, Learning Video, Physical Education, Online Learning

\begin{abstract}
This study aims to determine the parents' perception of the learning videos of physical education subjects given by the teacher to students in carrying out the teaching and learning process. This study uses quantitative research methods. The type of research used is survey research with data collection techniques in the form of a google form questionnaire. The sample of this study was the parents of students at SD Negeri 1 Landasan Ulin Utara, Banjarbaru City who were willing to fill out questionnaires from class $\mathrm{V}$ and III, obtained 113 respondent data. The data analysis technique used descriptive statistics which were presented using frequency and percentage tables. The results of this study indicate that the parents' perception of the learning video is quite good, it can be seen from the data of eight indicators, there are four indicators that are classified as good category (50\%), and four indicators are classified as moderate category $(50 \%)$.
\end{abstract}




\section{INTRODUCTION}

The spread of Covid-19 that occurred in 2020 greatly affected various aspects of life, including the world of education in Indonesia. The government issued a policy in the field of education through Circular Letter Number 03 of 2020 of the Ministry of Education and Culture regarding the Prevention of Corona Virus Disease (Covid-19) in education units related to the implementation of learning stating that the implementation of the teaching and learning process was carried out at home online. In line with the circular letter from the Ministry of Education and Culture, teachers are required to carry out distance learning at all levels and in every subject. For this reason, teachers are required to present alternative learning so that the teaching and learning process continues, especially the subjects of Physical Education, Sports and Health, which are subjects that are very dominant in the psychomotor aspect. In responding to this challenge, Physical Education and Sports teachers carry out learning by providing learning videos as a medium for delivering material and assigning motion. Elementary school levels in the city of Banjarbaru, especially Elementary School 1 Landasan Ulin Utara have carried out online learning and carried out the teaching and learning process at home, in the subject of Physical Education the teacher provides learning and assignments through learning videos. The learning video used is a video created and published by the Banjarbaru City Physical
Education teacher group on YouTube. Through learning videos provided by the teacher, students observe and learn every explanation and example of movement given by the teacher.

In this regard, changing the learning model from face to face to online will certainly affect one's perception. Perception is a person's meaning or view of an object or stimulus through observation using the senses (Karuru, 2018)). Perception in this case is the perception of parents of students as people who accompany the child's learning process at home during online learning where each parent will give a different perception. When carrying out teaching with online learning, researchers saw many obstacles that arise when carrying out online learning such as uneven internet connections in each area, and not all parents have the availability of devices that support their children's learning activities, so not all students can carry out learning activities. online in this case is access to learning videos provided by the teacher.

At the elementary school level, especially in the lower classes (grades 13 ), the role of parents is very important to assist and guide children in learning activities so that students can carry out learning at home. However, not all students can adapt directly to online learning because prior to the home study policy, both teachers, parents and students had never carried out remote or online learning before. Parents' perceptions of students in interpreting learning videos in 
the implementation of children's learning processes are also unknown.

Seeing this situation, knowing the perceptions of parents will describe how students' parents actually interpret the implementation of online learning in physical education subjects using learning videos provided by the teacher. Based on the above problems, there is a need for research to discuss parents' perceptions of learning videos provided by teachers in the implementation of online learning for their children. Through the perceptions of parents of students, teachers will be able to make changes and design correct learning videos in terms of designs, methods, subject matter and video presentations that are more attractive so that they can be easily understood and attract the attention of students. Thus the teacher will get maximum results in the teaching and learning process during the application of online learning. The online learning model is more efficiently used by teachers to achieve learning objectives by utilizing supporting devices and adequate networks. (Yanti, M. T., Kuntarto, E., \& Kurniawan, 2020). The application of online learning is an appropriate step given by the government so that students can continue to carry out learning that has been prepared according to the curriculum and at the same time avoid virus transmission in schools (Santika, 2020).

\section{METHODS}

The method used in this research is a survey method. The survey method according to (Sugiyono, 2015) "the survey method is used to get data from a certain natural place, but the researcher performs treatment in data collection.

\section{Participants}

The population in this study were parents of students in one upper class and one lower class, namely class III and V.

\section{Sampling Procedures}

The sampling technique in this study used the Simple Random Sampling technique. After the questionnaires were distributed and received by the parents of the students, 113 respondent data were obtained. This amount is the data processed by the researcher and is the sample in this study.

\section{Materials and Apparatus}

The instruments in this study with indicators 1) Perceived satisfaction in the use of learning video media 2). Opinion against the use of video media 3). Ease of using video media 4). Usefulness of learning video media in the learning process 5). Rate 6). Receive 7). Teacher's explanation 8). Video presentation

\section{Procedures}

The instrument in this study was a questionnaire using a Google Form with a Likert scale which was distributed online via the Whatsapp platform (Tri Irianto dan \& Arifin, 2020) by a teacher of Physical Education, Sports and Health at the State Elementary School 1 Landasan Ulin Utara, Banjarbaru City. The questionnaire consists of 42 statements from 8 indicators.

\section{Design or Data Analysis}

The research data is in the form of quantitative data which will be calculated using the percentage descriptive technique. The percentage descriptive data analysis technique is intended to 
determine the status of the variable, namely to describe student learning outcomes through percentages According to (Arovah, 2012)

\section{RESULTS}

In this study, the perceptions of parents of students towards the learning videos of Physical Education, Sports and Health subjects at the State Elementary School 1 Landasan Ulin Utara, Banjarbaru City during online learning were based on the indicators described as follows:

Table 1. Distribution results of all indicators

\begin{tabular}{ccc}
\hline Category & Frekuensi & Persentase \\
\hline Very good & 0 & $0 \%$ \\
\hline Well & 4 & $50 \%$ \\
\hline Currently & 4 & $50 \%$ \\
\hline Not good & 0 & $0 \%$ \\
\hline Not very good & 0 & $0 \%$ \\
\hline Amount & 8 & $100 \%$ \\
\hline
\end{tabular}

The results of the data in the table above can be displayed in the form of a diagram, seen in the image below:

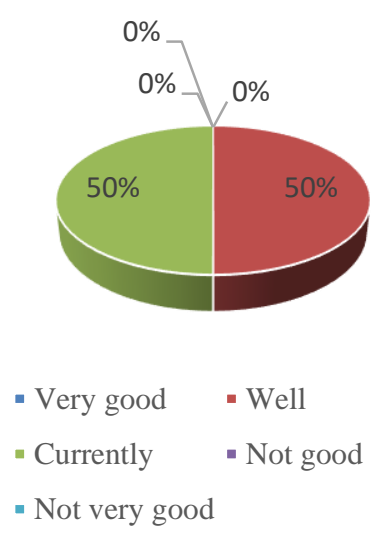

Figure 1. Percentage chart of all indicator categories

\section{DISCUSSION}

The following is a discussion of each indicator:

1. Satisfaction felt in the use of learning video media

The results showed that $50.4 \%$ or most of the perceptions of parents of students on the indicators of perceived satisfaction in the use of instructional video media were in the good category. These results can be interpreted that the satisfaction felt by most parents of students in the use of learning videos is quite good. This happens because parents of students think that learning through learning videos can help children understand learning material, and can help students carry out learning activities without having to come to school to avoid the spread of the virus. Based on this, it is in line with the opinion of (Meidawati, A.N, S., Bayu, 2019) about the advantages of online learning, one of which is time and cost efficiency, learning without being limited by time and space. The subject matter can be accessed by all students through devices connected to the internet, so that students can download subject matter and study at any time.

2. Opinion on the use of video media

The results showed that $53.1 \%$ or the majority of parents' perceptions of students' opinions on the use of video media were in the medium category. These results can be interpreted that most of the parents of students interpret the use of learning videos in the subjects of Physical Education, Sports and Health (PJOK) in the implementation of the distance learning process with a moderate level of 
perception. This is because PJOK subjects are dominant subjects in the psychomotor aspect and require direct interaction between teachers and students in the learning process. By changing the learning model from face-to-face to online or remotely, interaction will be limited and make students less understanding of the subject matter and have an impact on the achievement of PJOK learning objectives. Based on this, it is in accordance with the opinion of Ade Kusuma in (Hadisi, L., \& Muna, 2015) which states that one of the weaknesses of online learning is that the interaction between teachers and students or even between students and students is very minimal, which can hinder the formation of a value. in the learning process.

\section{Ease of Using Video Media}

The results showed that $54 \%$ or most of the perceptions of parents of students on the indicators of ease of using video media were in the medium category. These results can be interpreted that parents of students perceive that the ease of using learning videos is moderate. This is because to be able to use video media in the learning process, a device with special criteria is needed. Based on this, in line with the opinion of (Johari, A., Hasan, S., \& Rakhman, 2014) about the weaknesses of using video media in the learning process, one of which is that video media can only be used with computers and cellphones and internet connections. Besides that, Android-based learning media is very easy for students to use. (Titting, F., Hidayah, T., \& Pramono, 2016).
4. The Use of Learning Video Media in the Learning Process

The results showed that $57.6 \%$ or most of the perceptions of parents of students on the indicators of the usefulness of learning video media in the learning process were in the good category. These results can be interpreted that parents of students perceive that the usefulness of learning video media in the learning process is quite good. This is because parents of students assume that in carrying out the learning process for PJOK subjects through video learning at home, it creates a conducive learning environment and makes students more enthusiastic about learning and exercising at home during online learning and learning videos show examples of movements that make children better understand the subject matter. This is in line with the opinion of (Cahyani, A., Listiana, I. D., \& Larasati, 2020) which states that one of the external factors that play a role in influencing students' learning motivation is the condition of the learning environment, a conducive learning environment will support and strengthen the learning spirit of students.

\section{Assess}

The results showed that $73.4 \%$ or the majority of the perceptions of parents of students on the indicators of assessing belonged to the medium category. These results can be interpreted that parents of students have a level of perception that is classified as moderate in assessing learning videos. This is because in their experience guiding and assisting the child's learning process at home, parents of 
students assess the subject matter is very difficult to practice at home, the examples of movements shown in the learning videos are too short which makes it difficult for children to observe examples of movements, and parents also judge that evaluation of learning videos needs to be done in order to produce good learning videos. In online learning, teachers need to assess during the learning process aspects of affective (social attitude), cognitive, and psychomotor. Communication is an important point for carrying out learning using distance simulation methods and especially assessment techniques (Rahmadi dan Tri Irianto, 2021)

\section{Receive}

The results showed that $56.6 \%$ or most of the perceptions of parents of students on the indicator of acceptance belonged to the medium category. These results can be interpreted that parents of students have a level of perception that is classified as moderate in receiving learning videos. This is because in their experience guiding and assisting children's learning process at home, parents of students have the view that the learning process should be done face-to-face not through learning videos, but on the one hand parents of students also support the use of learning videos in the learning process at home. home so that the child's learning process continues during the pandemic to prevent being infected with the virus.

\section{Teacher's Explanation}

The results showed that $57.5 \%$ or most of the perceptions of students' parents on the teacher's explanation indicators were in the good category. These results can be interpreted that the perception of parents of students on the teacher's explanation in the learning video is quite good. This is because the language used by the teacher can be understood easily by students, the use of words and sentences from the teacher is quite good, and the teacher's voice when explaining the subject matter can be heard clearly.

\section{Video Presentation}

The results showed that $81.4 \%$ or the majority of parents' perceptions of students on video presentation indicators were in the good category. These results can be interpreted that the perception of parents of students on the presentation of learning videos is quite good. This is because the music in the learning video makes the video more fun, the color variations are very diverse, and the animation in the learning video makes students happy to pay attention to the learning video, and the writing in the learning video can be easily read by students. In line with the opinion of (Arnesti, N., \& Hamid, 2015) about the advantages of implementing online learning through learning videos, one of which is to provide more learning experiences, with text, audio, video and animation, all of which are used to convey information. Good learning videos will have an impact during learning (Hadiana, O., Wahidi, R., Sartono, S., Agustan, B., \& Ramadan, 2020) (Jayul, A., \& Irwanto, E.Jayul, A., \& Irwanto, 2020). 


\section{CONCLUSION}

Based on the results of the research that has been described, it can be concluded that the parents' perception of learning videos is classified as quite good, of the eight indicators there are four indicators that are classified as good (50\%) and four indicators are classified as moderate $(50 \%)$, this is evident from the results data analysis in terms of satisfaction indicators with good categories reaching $50.4 \%$, usability indicators in good categories reaching $64.6 \%$, teacher explanations in good categories reaching $57.5 \%$, and video presentation in good categories reaching $81.4 \%$, and while the indicators of opinion on videos in the medium category reached $53.1 \%$, the ease with the medium category reached 54\%, judged the medium category reached $73.4 \%$, and received videos in the medium category reached $56.6 \%$.

\section{ACKNOWLEDGEMENT}

Thanks to Dean of the FKIP and Rector of Lambung Mangkurat University who have supported the writing of this article.

\section{REFERENCES}

Arnesti, N., \& Hamid, A. (2015). Penggunaan Media Pembelajaran Online - Offline Dan Komunikasi Interpersonal Terhadap Hasil Belajar Bahasa Inggris. Urnal Teknologi Informasi \& Komunikasi Dalam Pendidikan, 2(1). https://doi.org/https://doi.org/10.24114/jt ikp.v2i1.3284

Arovah, N. I. (2012). Status Kegemukan, Pola
Makan, Tingkat Aktivitas Fisik Dan Penyakit Degeneratif Dosen Dan Karyawan Universitas Negeri Yogyakarta. MEDIKORA, 1(5).

Cahyani, A., Listiana, I. D., \& Larasati, S. (2020). Motivasi Belajar Siswa SMA pada Pembelajaran Daring di Masa Pandemi Covid-19. Jurnal Pendidikan Islam, 3(1), 123-140.

Hadiana, O., Wahidi, R., Sartono, S., Agustan, B., \& Ramadan, G. (2020). Efektivitas penerapan video feedback (VFB) terhadap motivasi belajar pada pembelajaran futsal. Jurnal SPORTIF: Jurnal Penelitian Pembelajaran, 6(1), 184-198.

Hadisi, L., \& Muna, M. (2015). Pengelolaan Teknologi Informasi Dalam Menciptakan Model Inovasi Pembelajaran ( ELearning ). Jurnal Al-Ta'dib, 08(1), 117140.

Jayul, A., \& Irwanto, E.Jayul, A., \& Irwanto, E. (2020). Model Pembelajaran Daring Sebagai Alternatif Proses Kegiatan Belajar Pendidikan Jasmani di Tengah Pandemi Covid-19. Jurnal Pendidikan Kesehatan Rekreasi, 6(2), 190-199.

Johari, A., Hasan, S., \& Rakhman, M. (2014). Penerapan Media Video Dan Animasi Pada Materi Memvakum Dan Mengisi Refrigeran Terhadap Hasil Belajar Siswa. Journal of Mechanical Engineering Education, $1(1), \quad 5$. https://doi.org/https://doi.org/10.17509/j mee.v1i1.3731

Karuru, P. (2018). Persepsi Peserta Didik Terhadap Interaksi Pembelajaran IPA Fisika di SMP Negeri 3 Mengkendek. In Neutrino, 1(1), 5.

Meidawati, A.N, S., Bayu, \& R. (2019). Persepsi Siswa Dalam Studi Pengaruh Daring Learning Terhadap Minat Belajar Ipa. SCAFFOLDING: Jurnal Pendidikan Islam Dan Multikulturalisme, 1(2), 3038. https://doi.org/https://doi.org/10.37680/s 
caffolding.v1i2.117

Rahmadi dan Tri Irianto. (2021). Implementation of Simulation Models for Learning Physical Education during the COVID-19 in Banjarmasin. Turkish Journal of Computer and Mathematics Education (TURCOMAT), 12(6), 46374642.

Santika, I. W. E. (2020). Pendidikan karakter pada pembelajaran daring. Indonesian Values and Character Education Journal, 3(1), 8-19.

Sugiyono. (2015). Metode Penelitian \& Pengembangan Research And Development. Bandung: Alfabeta.

Titting, F., Hidayah, T., \& Pramono, H. (2016). Pengembangan Multimedia Pembelajaran Senam Lantai Berbasis Android Pada Pendidikan Jasmani Olahraga Dan Kesehatan Di Sma. Journal of Physical Education and Sports, 5(2), 120-126.

Tri Irianto dan, \& Arifin, R. dan M. F. (2020). The Relationship of Physical Activities and Student Learning Outcomes of Physical Education. Kinestetik: Jurnal Ilmiah Pendidikan Jasmani, 5(2), 318325.

https://doi.org/https://doi.org/10.33369/j k.v5i2.16376

Yanti, M. T., Kuntarto, E., \& Kurniawan, A. R. (2020). Pemanfaatan Portal Rumah Belajar Kemendikbud Sebagai Model Pembelajaran Daring di Sekolah Dasar. Adi Widya: Jurnal Pendidikan Dasar, 5(1), 61-68. 